\title{
CONDITIONING AND ELECTRO-PHYSIOLOGY
}

\begin{abstract}
A
PAVLOVIAN Conference on "Higher Nervous Activity" was held during October 13-15 in New York, under the auspices of the New York Academy of Sciences and the Academy of Medical Sciences of the U.S.S.R. This Conference follows, in its main lines, a number of recent international meetings such as the Moscow Colloquium on "Electroencephalography and Higher Nervous Activity", the Montevideo Symposium on "Brain Mechanisms and Learning", and the Macy Conference series on the "Central Nervous System and Behaviour". These Conferences have been promoted because of widespread belief, explicitly stated by Magoun in his contribution to the New York Conference, that "the most striking recent progress in the biology of Higher Neural Activity has unquestionably come from electrophysiological analyses of the mechanism of learned behaviour. Knowledge has especially been advanced by marriage between the electrical recording techniques of Western neurophysiology and the classical Pavlovian approaches to the study of conditioned reflexes cultivated so extensively in the U.S.S.R.". The proceedings of the entire meetings will be published in the Annals of the New York Academy of Sciences. Attendance at the meetings averaged about eight hundred persons on each of the three days.
\end{abstract}

How does this Conference conform to a reformulation of Parkinson's law, namely, that regardless of new material available the number of words spoken at a conference will expand to fill the Proceedings published a year or two later? On the whole, expectations are fulfilled. There are some semiphilosophical discussions "on the relationship between neurophysiology, psychophysiology, psychopharmacology and other disciplines", which are not likely to throw much light on the difficult task of analysing the cortical and subcortical events taking place during conditioning. We have a rather expanded account of "The Role of Slow Waves in Differential Inhibition" based on records obtained from electrodes implanted with unknown accuracy "in the visual cortex, auditory cortex, medial suprasylvian cortex, dorsal hippocampus, ventral hippocampus, mesencephalic reticular formation, centralis lateralis, centre median, medialis dorsalis, and the lateral geniculate body" of two cats in which the conditioned avoidance response to flickering light was established. The results of this "admittedly crude and exploratory pilot study" are not particularly informative; conclusions are of the nature that "our electrographic data indicate that cortical slow waves are associated with inhibition, although they do not preclude excitation"; and we also have "The First Law of Bio-Cybernetics : Unidirectional Rate Sensitivity", which attempts a mathematical expression of heartrate and pupillary reflexes. This paper will, no doubt, appeal to mathematicians familiar with Laplace operators, but will leave most biologists doubtful about the applicability of this type of analysis to sets of data still very much in search of appropriate causal factors.
From the point of view of the Western reader, no doubt the most interesting and important papers will be the Russian ones, particularly those by P. K. Anokhin and E. A. Asratyan. These not only give a summary of work done over the years in the laboratories of these two contributors but also report work which, to the present reviewer at least, was unknown and interesting.

Anpkhin, after directing attention to the fact that many years ago Pavlow had already emphasized the importance of subcortical centres in ensuring a "high energy level for the functional interactions among the cortical elements", began his talk "with a formulation of some perfectly obvious contradictions which are now arising between the basic ideas of modern instrumental neurophysiology and the physiology of higher nervous activity. ... The main contradiction is in the understanding of the essence of the ascending non-specific activity effect of the reticular formations of the stem and thalamus on the cerebral cortex". The problem, as it appears to Anokhin, is this: "The generally accepted interpretation of this phenomenon assumes that this effect is generalized throughout the entire cortex and prohably all the cortical cellular elements. Desynchronization, that is, transformation of the slow-wave and high-amplitude electric activity into low-amplitude and highfrequency electric activity, is usually regarded as electrophysiological expression of this generalized activation. . . It is silently assumed that this activity concerns all the cell elements of the cortex, hence, its designation as 'diffuse' activity".

This diffuse and non-specific activity contrasts with the very highly specific formation of conditioned reflexes, that is, the creation of "the temporary bond between the given stimulus and any inborn activity of the organism". As Anokhin puts his problem: "How can generalized and apparently diffuse activation of the cerebral cortex be combined with the finest selective interactions between the cortical elements down to and including individual synaptic contacts ?" Anokhin's very lengthy address summarizes the extensive work of his school relating to this problem, which has proceeded along two main lines. In the first place he has made a comparative evaluation of the activating effect of the cerebral cortex under conditions of two biologically opposed states of the animal-defensive and alimentary ; and secondly, he has worked by means of stereotaxic placement and micro-electrode techniques of evoked potential. He studied "the ways of the ascending influences on the cortical element under different pharmacological effects and at different stages of ontogenetic development". The results of all this work are interpreted by him as throwing considerable doubt on the notion of 'diffuseness' as applied to the activating effects of the subcortical structures.

Asratyan is concerned with "The Question of the Initiation and Localization of Various Types of Cortical Inhibition in the Elements of the Conditioned Reflex Arc". He opposes both the two traditional 
views, that is, "that conditioned inhibition is initiated in the cortical nerve cells of the focus of the conditioned stimulus", as well as the alternative view, "that conditioned inhibition is initiated in the nerve cells of the focus of the unconditioned stimulus". (He also rejects the view of Kupalov, which combines these two hypotheses.) Asratyan's own theory amounts to saying "that conditioned inhibition is initiated primarily in the elements of the conditioned connexion itself, which we represent as a chain of internuncial neurones". Most of the work he quotes in support comes from experiments on "transswitching" ; this term is used by him to designate an experimental paradigm in which ". . . a single indifferent stimulus is given two different signal values at the same time. This is done by reinforcing the stimulus differently in two different experimental conditions or situations". These experiments are interesting, but scarcely conclusive; Asratyan does not, for example, discuss at all the difficulties which would be presented for his theory by the results of Culler's classical experiment of 1938.

It is noteworthy that, while the American and Russian participants at this Conference do occasionally take notice of each other's work, yet in the main there is no real bridge from one group of workers to the other. This may be a question of nationality and politics; but other possibilities spring to mind. Electro-physiologists in the United States, and in Great Britain too, pay just as little attention to the work, or the contribution, of Western psychologists active in the field of modern learning theory and conditioning as they do to the Russians; the encapsulation of separate disciplines is more likely to be the villain of the piece, rather than national or political prejudices.
H. J. EYSENCK

\section{THE CHANGING INDUSTRIAL ENVIRONMENT}

$\mathrm{T}$

HE theme of the annual conference of the Institute of Personnel Management which was held at Harrogate during October 7-9 was "People and Machines".

Various developments in personnel management and industrial relations were considered by the 1,200 individuals who attended from industrial companies, local and central government departments, universities and other higher educational institutions throughout the world. The tone and conduct of the conference were again on such a high plane that it is bound to have far-reaching consequences. Responsibility for organizing a conference which, outside those of political parties and trade unions, is probably the biggest in Great Britain lies mainly with Miss H. E. Cutting, who must be congratulated for the quietly efficient way in which these conferences take place.

The opening address was given by the newly appointed Minister of Labour, the Rt. Hon. John Hare, who, after reviewing the general principles on which the Government acts in the field of industrial relations, described the measure of success which stems from the British system of free negotiation. In the twelve months from June 1959 to June 1960, for example, more than 300 important claims for increased wages or shorter hours covering practically the whole of industry were settled peacefully, while less than ten resulted in disputes which led to strikes.

Strikes can be put broadly into two categories. First, there are strikes over clear-cut economic issues affecting wages or conditions of work. These, if they take place after the procedure of negotiation has been followed and failed to produce agreement, are one of the consequences to be accepted as inevitable from time to time in a free society where those who work have the right and power to seek the conditions of employment they feel that they are entitled to.

The second category contains the large number of strikes in individual establishments over a wide variety of difficulties, not only wages, which arise between management and labour or between different groups of workers. They arise over such issues as discipline, dismissals, redundancy, working arrangements and union membership. The causes of many of them are sometimes obscure-at least to the general public. Most of them are unofficial.

This second category of strike has recently given rise to public criticism. Industry itself, both employers and trade unions, is gravely concerned about them. Mr. Hare indicated that these criticisms and fears are justified because these strikes indicate continuing weakness in the present system. The Minister recommended that the two sides of the motorcar manufacturing industry should set up a top-level study group, or informal committee, to produce constructive proposals for overcoming the problems which cause regrettable stoppages within the industry -wnether these problems arise on the management or the workers' side. The Minister indicated his readiness to help such a group.

At one of the sectional meetings the issue of whether collective bargaining should be carried out nationally or locally was examined. Prof. E. H. Phelps Brown showed how, in the years of full employment sinee the Second World War, there has been a substantial increase in the extent to which actual terms and conditions of employment are regulated by bargaining between firms and their own workpeople. Much of our collective bargaining now has a two-tier structure : from time to time each employee gets a rise the amount of which is fixed by an industrywide bargain, but this actual rate depends also on a bargain struck within the firm. The procedure by which these local agreements are reached vary widely, and many are informal, but, in one way or another, they involve negotiation between a firm's manayement and its own work-people.

Is this development to be welcomed or resisted ? Negotiation firm by firm avoids the danger of industrywide bargaining and that rises in money wages will be granted too readily, because all competitors will have to pay them and so expect to be able to cover them by a general rise in selling prices. On the other hand, there is a danger that the different rates for the same job in different firms will give rise to unrest and whip-sawing.

Mr. G. Moxon, of United Glass, Ltd., was firmly against any proposal to decentralize wage-rate bargaining. Such a proposal presents a major 